\title{
YIELD RESPONSE OF WINTER WHEAT (TRITICUM AESTIVUM L.) TO WATER STRESS IN NORTHERN CHINA: A META-ANALYSIS
}

\author{
JinG, B. H. - WANG, C. - KHAN, S. - YuAN, Y. C. - YANG, W. D. ${ }^{*}$ FenG, M. C. \\ College of Agriculture, Shanxi Agricultural University, Taigu, China \\ (phone: +86-1580-3431-035) \\ *Corresponding authors \\ e-mail: sxauywd@126.com; phone:+86-1383-4835-129 (Yang, W. D.) \\ e-mail: fmc101@163.com; phone:+86-1383-4838-834 (Feng, M. C.) \\ (Received $7^{\text {th }}$ Sep 2019; accepted $14^{\text {th }}$ Nov 2019)
}

\begin{abstract}
Water deficit is one of the main environmental constraints affecting the yield of winter wheat. We quantified the effect of water stress on the grain yield of winter wheat in northern China, by using meta-analysis method. Database was obtained through 1921 experimental observations derived from 53 research articles of the 2000 to 2017 period. The results showed that the grain yield was significantly affected by the water and latitude. Grain yield and number of spikes $\left(\mathrm{ha}^{-1}\right)$ increased with the total water from $1001 \mathrm{~m}^{3} \mathrm{ha}^{-1}$ to $4000 \mathrm{~m}^{3} \mathrm{ha}^{-1}$. However, grain yield and number of spikes did not increase further at higher rates $\left(>4000 \mathrm{~m}^{3} \mathrm{ha}^{-1}\right)$. The grain yield, number of spikes and thousand grain weight were higher at a total water of 1-1000 $\mathrm{m}^{3} \mathrm{ha}^{-1}$, than those at $1001-2000 \mathrm{~m}^{3} \mathrm{ha}^{-1}$. Water stress had no significant effect on grain number per ear. The grain yield first increased with the latitude to a maximum of $36-37^{\circ}$ and then decreased with increasing latitude $\left(>37^{\circ}\right)$. In conclusion, the maximum yield of winter wheat was attained at $36-37^{\circ}$ latitude and $3001-4000 \mathrm{~m}^{3} \mathrm{ha}^{-1}$ total water.
\end{abstract}

Keywords: crop, drought stress, yield components, latitude, integrated analysis

\section{Introduction}

Water is essential for ensuring agricultural productivity. As a result of global warming, water shortages are becoming a major problem affecting the sustainable production of global crops (Sauer et al., 2010; Cai et al., 2011). Studies have shown that the frequency and intensity of droughts will be increased in future, which may lead to severe declines in future crop yield (Dai, 2012; Daryanto et al., 2016). The wheat (Triticum aestivum L.) which is the second largest cereal crop in the world is very susceptible to water stress (Reyer et al., 2013). Under water stress, plants tend to close leaf stomata to reduce transpiration loss, which adversely affects its physiological processes and nutrient uptake finally leading to the decreased yield (Rossini et al., 2013; Zhang et al., 2017a). The yield components (spike number, grain number, and grain weight) directly affect the formation of wheat yield. Moderate drought can affect grain weight, and severe water shortage will lead to an obvious decrease in the spikelets and grain numbers (Giunta et al., 1993). Moderate water stress occurred at a certain stage of wheat, after re-watering could make a positive effect on the growth and developments of wheat and its yield compensation. Therefore, it is not always necessary to maintain sufficient water throughout the growing period of wheat, which may cause excessive vegetative growth and lower the economic coefficient. Moreover, due to the uneven distribution of water resources in region and time in China, and the traditional irrigation rate is always excessive which is $1 \sim 1.5$ times than the demand of crops, the problem of low water efficiency seriously restricts China's agricultural development (Du et al., 
2010; Wei et al., 2018). Therefore, how to scientifically use water, how to improve water use efficiency, and how to formulate effective water-saving agricultural practices are major issues that needs to be urgently solved in current years.

The degree of water stress of wheat in different regions is different, and the influence of temperature on it can't be ignored. Temperature is critical for controlling winter wheat growth and yield (Asseng et al., 2011; Farhangfar et al., 2015). Water stress is expected to increase in the future, and water stress may reduce crop yields in many parts of the world (Qin et al., 2018). Increased temperature shortens the duration of the wheat growing season, resulting in a decline in yield, and Temperature differences in different regions also indicate differences in latitude. Latitude is an important geographic factor that significantly affects temperature, sunshine hours and crop growth (Liu et al., 2013b). However, under different degrees of water stress, the variation of wheat yield with latitude remains to be studied. Therefore, this paper studied the variation of wheat yield under different degrees of water stress, and hoped that the results could improve our quantitative understanding of the impact of water stress on wheat yield in China.

Meta-analysis can quantitatively synthesize existing test data, systematically analyze the combined effects and influencing factors of specific measures, and determine the general trends in many independent experiments (Hedges et al., 1999). At present, most of the experiments on wheat water stress focus on the scale of individual test sites, and the results are not consistent due to differences in factors such as climate, soil and planting system. Therefore, present study was designed to study the effect of water stress and latitude on the yield and yield components of winter wheat in northern China based on the meta-analysis method.

\section{Materials and methods}

\section{Data collection and classification}

Various English (Web of Science, Google Scholar, Science Direct, Wiley online library, Springer) and Chinese (CNKI) databases were searched by using keywords: wheat, yield, water stress, water deficiency, China and their combinations. The articles related with water stress on winter wheat in China from 2000-2017 were collected and screened on the basis of the following criteria: (1) area was located in northern China and year and latitude and longitude of the test site was clearly mentioned; (2) the test plot was a field whereas pot experiments were not included; (3) the experimental study had a water stress treatment and also a well-watered control; (4) only the water stress as treatment along with control, and yield data were collected in the multi-factor study, whereas, other treatments were routinely processed in the local field. As a result of screening, 53 research articles containing 486 sets of data and 1921 test observations were obtained (Fig. 1). The distribution of study site was shown in (Fig. 2).

The sum of the irrigation rate and rainfall during the growth period of wheat (if test areas have no canopy to protect from rainfall) was taken as the total water, in order to investigate the effect of different the total water on winter wheat yield the collected data were classified into 5 irrigation ranges (Table 1). The treatment with no external irrigation and rainfall was taken as the control in study (total water is 0). Latitude of each test site was divided into four categories as: $34-35^{\circ}, 35-36^{\circ}, 36-37^{\circ},>37^{\circ}$, and $34-$ $35^{\circ}$ was taken as the control. Moreover, as only one experimental site having latitude $<34^{\circ}$ was obtained, which is not enough for meta-analysis, so this latitude was excluded (Red sites in Fig. 2). 


\section{Study site}

The study site is located at $34^{\circ}-39^{\circ}$ north latitude and $103^{\circ}-121^{\circ}$ east longitude, in the Loess Plateau and the North China Plain (Fig. 2). It is dry in winter and has four distinct seasons and the coldest is in January, the precipitation is $400-800 \mathrm{~mm}$ and is concentrated in July and August and it belongs to monsoon climate of medium latitudes and temperate continental climate. The soil is mainly cinnamon soil and loessial soil. The cinnamon soil has a neutral to slightly alkaline reaction, the middle and lower parts have the accumulation of clay particle and calcium. The loessial soil is soft soil and organic matter content is low, has strong calcareous reaction and good water permeability and cultivability.

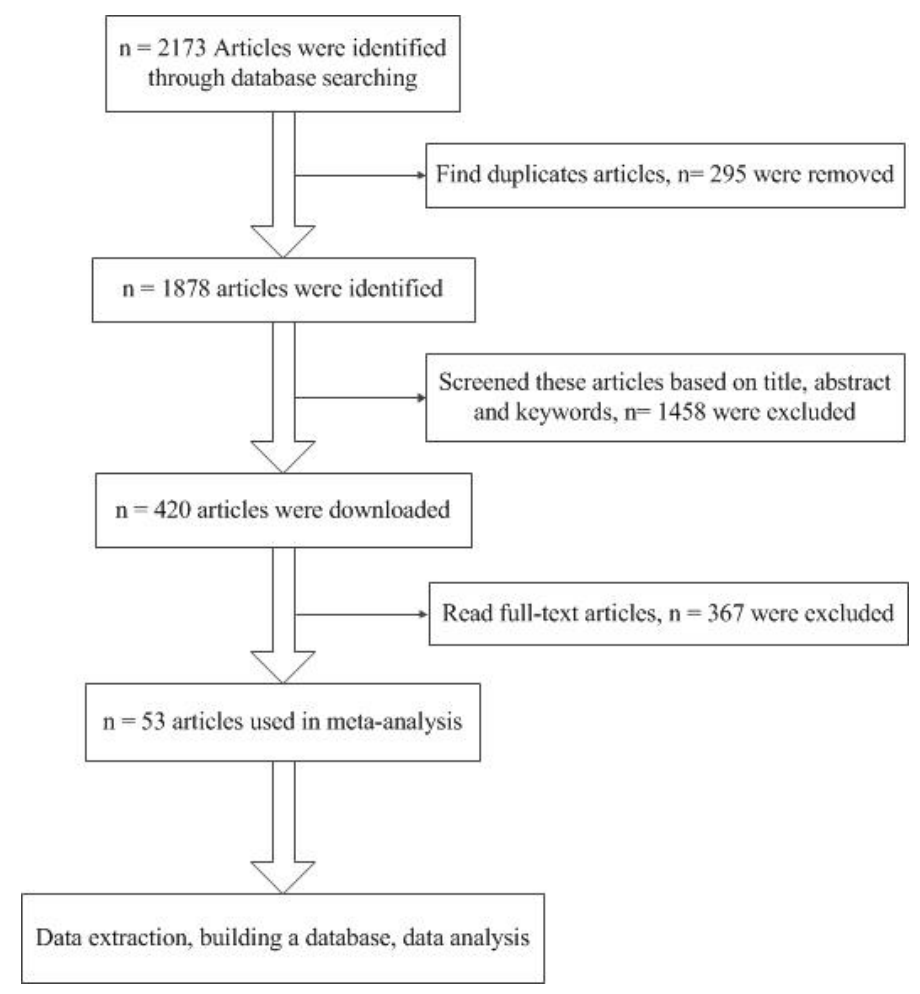

Figure 1. Flowchart of the process of building the database and meta-analysis

\section{Data processing}

Data analysis was performed using the integrated analysis method described by Hedges and Olkin (Hedges and Olkin, 1985). The effect size of water stress on GY, SN, GN and GW was evaluated by standardized mean difference (SMD), which is the relative value of the overlap between the two sets of data, and reflects the difference and representativeness between each other:

$$
\begin{gathered}
g=\frac{\left(\overline{\mathrm{X}}_{\mathrm{E}}-\overline{\mathrm{X}}_{\mathrm{C}}\right)}{\mathrm{S}_{\text {within }}}\left(1-\frac{3}{4\left(\mathrm{~N}_{\mathrm{C}}+\mathrm{N}_{\mathrm{E}}-2\right)-1}\right) \\
\mathrm{S}_{\text {within }}=\sqrt{\frac{\left(\mathrm{N}_{\mathrm{E}}-1\right)\left(\mathrm{S}_{\mathrm{E}}\right)^{2}+\left(\mathrm{N}_{\mathrm{C}}-1\right)\left(\mathrm{S}_{\mathrm{C}}\right)^{2}}{\mathrm{~N}_{\mathrm{E}}+\mathrm{N}_{\mathrm{C}}-2}}
\end{gathered}
$$




$$
V_{g}=\left(\frac{\mathrm{N}_{\mathrm{C}}+\mathrm{N}_{\mathrm{E}}}{\mathrm{N}_{\mathrm{C}} \mathrm{N}_{\mathrm{E}}}+\frac{\mathrm{d}^{2}}{2\left(\mathrm{~N}_{\mathrm{C}}+\mathrm{N}_{\mathrm{E}}\right)}\right)\left(1-\frac{3}{4\left(\mathrm{~N}_{\mathrm{C}}+\mathrm{N}_{\mathrm{E}}-2\right)-1}\right)^{2}
$$

where $\bar{X}_{E}$ and $\bar{X}_{C}$ are the average values of the treatment and the control group, $g$ is standardized mean difference; $\mathrm{N}_{\mathrm{E}}$ and $\mathrm{N}_{\mathrm{C}}$ are the number of samples for the treatment and control groups; $V_{g}$ is the variance of the independence study; $\mathrm{S}_{\mathrm{E}}$ and $\mathrm{S}_{\mathrm{C}}$ were the standard deviations of all comparisons between treatment and control, respectively, and $\mathrm{S}_{\text {within }}$ was the composite standard deviation within each study group. When studies do not report standard deviation, the missing standard deviation values were estimated by calculating the average coefficient of variation between each data set.

The combined effects and confidence intervals were calculated as follows:

$$
\begin{gathered}
W=\frac{1}{\mathrm{~V}_{\mathrm{g}}} \\
M=\frac{\sum_{\mathrm{i}=1}^{\mathrm{k}} \mathrm{W}_{\mathrm{i}} \mathrm{g}_{\mathrm{i}}}{\sum_{\mathrm{i}=1}^{\mathrm{k}} \mathrm{W}_{\mathrm{i}}} \\
V_{M}=\frac{1}{\sum_{\mathrm{i}=1}^{\mathrm{k}} \mathrm{W}_{\mathrm{i}}} \\
S E_{M}=\sqrt{\mathrm{V}_{\mathrm{M}}} \\
L L_{M}=\mathrm{M}-1.96 * \mathrm{SE}_{\mathrm{M}}, \quad \mathrm{UL}_{\mathrm{M}}=\mathrm{M}+1.96 * \mathrm{SE}_{\mathrm{M}}
\end{gathered}
$$

In the equation, $\mathrm{W}$ is the weight of each independent study; $\mathrm{M}$ is the weighted mean; $\mathrm{VM}$ is the variance of the combined effect; $\mathrm{SE}_{\mathrm{M}}$ is the standard error of the combined effect; $\mathrm{LL}_{\mathrm{M}}$ and $U \mathrm{~L}_{\mathrm{M}}$ are the upper and lower limits of the $95 \%$ confidence interval.

The relevant indicators in study were continuous variables, and the standardized mean difference after the integrated analysis represented the effect of different total water on wheat yield under water stress. Variables GY, SN, TGW and GN under different total water were calculated by the fixed- or random-effects model using software Revman (version 5.3, The Cochrane Collaboration, 2014). In this study, the inverse variance and the standardized mean difference were used as the effect size of the statistical measures and the meta-analysis, respectively. Random-effect model was used for moderate to high heterogeneity $\left(X^{2}>50 \%\right.$ and a chi-square $P$-value $\left.<0.05\right)$ (Smithers et al., 2008). The heterogeneity test of the data in this paper reached a significant level $\left(P_{Q}<0.05\right)$, so a random effects model was used. The difference between total water and the control was measured by the number of samples and the standard deviation. Confidence interval was finally generated by the effect size. If the $95 \%$ confidence interval size for a variable didn't cover 0 , it indicated that irrigation treatment had a significant effect on yield compared to control. Engauge digitizer was used to extract data such as histograms in paper. 


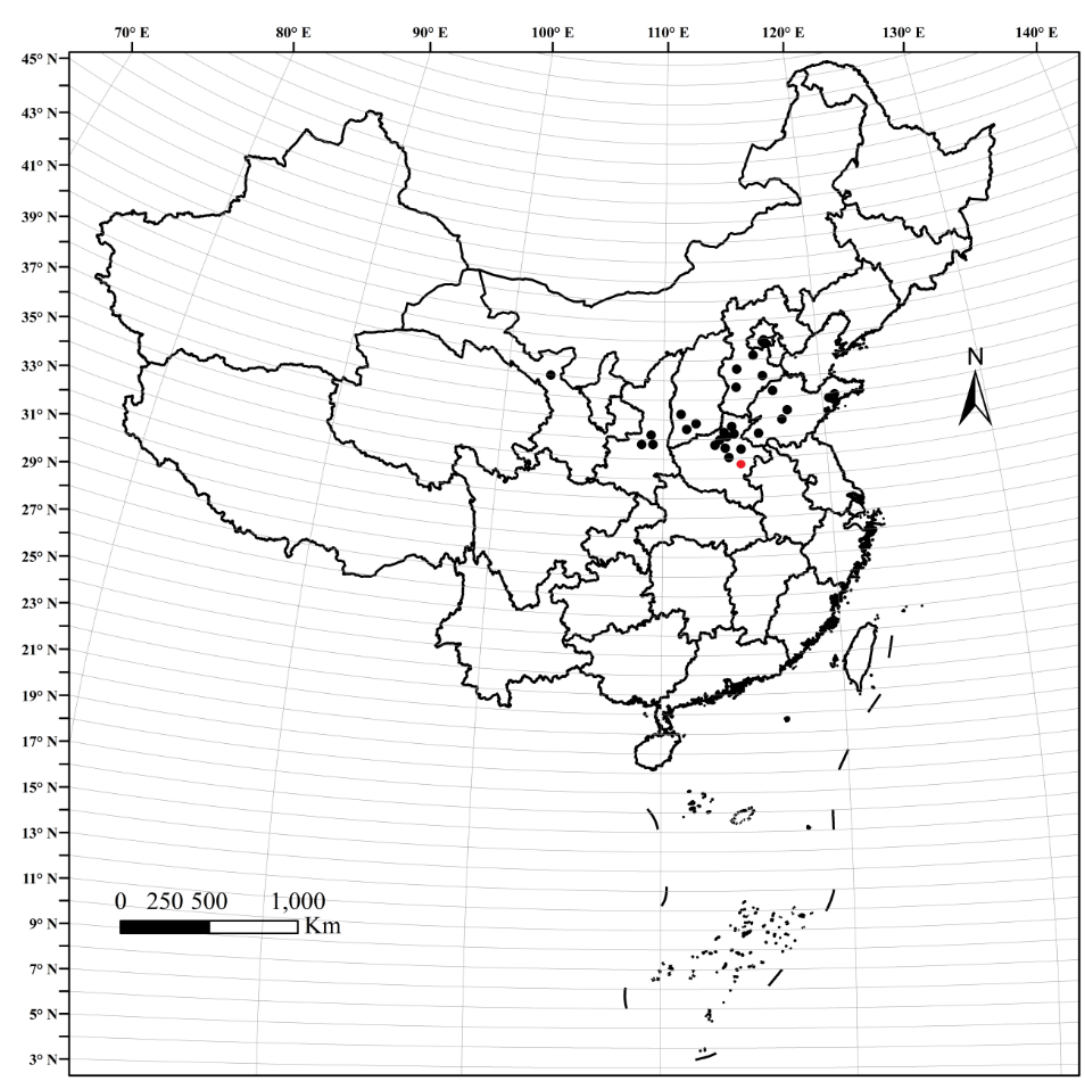

Figure 2. Distribution of selected experimental sites studied in this meta-analysis in northern China

Table1. Variables included in the meta-analysis

\begin{tabular}{l|l|l}
\hline Category & Variables & Abbreviations \\
\hline \multirow{4}{*}{ Yield } & Grain yield & GY \\
& Spike number & SN \\
& Grain number & GN \\
& Thousand grain weight & TGW \\
\hline & $1-1000$ & W1 \\
Total water $\left(\mathrm{m}^{3} \mathrm{ha}^{-1}\right)$ & $1001-2000$ & W2 \\
& $2001-3000$ & W3 \\
& $3001-4000$ & W4 \\
& $>4000$ & W5 \\
\hline
\end{tabular}

\section{Results}

\section{Heterogeneity test analysis}

The obtained data was analyzed by heterogeneity test and the results are shown in (Table 2). Results showed that the P-values of the meta-analysis of GY, SN and TGW were all less than 0.05 , which indicated the data were statistically significant and can be used for further meta-analysis. However, the meta-analysis P-value for GN was greater than 0.05, which mean it was not statistically significant. All P-value of heterogeneity test were greater than 0.05 and $\mathrm{I}^{2}$ was less than $50 \%$, indicating that there was no significant heterogeneity in each group of data. 
Table 2. Heterogeneity analysis of yield and yield components of winter wheat under different total water

\begin{tabular}{|c|c|c|c|c|c|}
\hline \multirow{2}{*}{ Variables } & & \multirow[b]{2}{*}{ No. of samples } & \multirow{2}{*}{$\begin{array}{l}\text { Meta-analysis } \\
(P \text {-value })\end{array}$} & \multicolumn{2}{|c|}{ Heterogeneity } \\
\hline & & & & $\mathrm{I}^{2}(\%)$ & \begin{tabular}{|l|}
$\begin{array}{l}\text { Chi-square test } \\
(P \text {-value })\end{array}$ \\
\end{tabular} \\
\hline \multirow{5}{*}{$\mathrm{GY}\left(\mathrm{kg} \mathrm{ha}^{-1}\right)$} & W1 & 51 & $<0.0005$ & 4 & 0.21 \\
\hline & W2 & 117 & $<0.00001$ & 0 & 0.33 \\
\hline & W3 & 189 & $<0.00001$ & 17 & 0.46 \\
\hline & W4 & 103 & $<0.00001$ & 21 & 0.27 \\
\hline & W5 & 72 & $<0.0001$ & 18 & 0.32 \\
\hline \multirow{5}{*}{$\mathrm{SN}\left(10^{4} \times \mathrm{ha}^{-1}\right)$} & W1 & 33 & 0.03 & 0 & 0.83 \\
\hline & W2 & 89 & 0.005 & 0 & 0.70 \\
\hline & W3 & 125 & $<0.0001$ & 1 & 0.66 \\
\hline & W4 & 73 & $<0.0001$ & 12 & 0.40 \\
\hline & W5 & 56 & 0.008 & 4 & 0.44 \\
\hline \multirow{5}{*}{ TGW(g) } & W1 & 32 & 0.01 & 8 & 0.13 \\
\hline & W2 & 101 & $<0.0001$ & 5 & 0.18 \\
\hline & W3 & 138 & $<0.00001$ & 33 & 0.06 \\
\hline & W4 & 71 & 0.002 & 23 & 0.09 \\
\hline & W5 & 49 & 0.03 & 12 & 0.20 \\
\hline \multirow{5}{*}{ GN } & W1 & 45 & 0.12 & 0 & 0.84 \\
\hline & W2 & 103 & 0.08 & 0 & 0.91 \\
\hline & W3 & 135 & 0.06 & 0 & 0.81 \\
\hline & W4 & 89 & 0.06 & 0 & 0.77 \\
\hline & W5 & 70 & 0.1 & 0 & 0.88 \\
\hline
\end{tabular}

GY: grain yield; SN: spike number per hectare; TGW: thousand grain weight; GN: grain number per ear; W1, W2, W3, W4 and W5 were total water

\section{Response of wheat yield to water stress}

A meta-analysis of winter wheat yield in northern China showed that GY was affected by different total water (Fig. 3). The 95\% confidence interval of GY effect size did not overlap with 0 indicating that the total water had a significant positive effect on GY. GY increased gradually with increasing the total water from W2 to W4. The GY reached the maximum at $\mathrm{W} 4$ and was decreased at W5. The GY at W1 was slightly higher than W2. The average increase of GY at W4 was 148\% relative to control.

\section{Response of wheat yield components to water stress}

The results indicated the $\mathrm{SN}$ and TGW were significantly affected by total water (Fig. 4). The SN and TGW at W1 were higher than W2, and SN was increased by increasing total water from $\mathrm{W} 2$ to $\mathrm{W} 4$. The $\mathrm{SN}$ at W4 was $39.7 \%$ higher than control. The TGW was highest at W3, which was $79.7 \%$ higher than control. The $95 \%$ confidence interval of GN effect size contains 0 , which indicate that different total water have no significant effect on GN.

\section{Effect of latitude on winter wheat yield}

It can be seen that winter wheat yield under different total water responded differently at different latitudes (Fig. 5). The GY at total water of W0, W2, W3 and W4 was significantly positive effect by increasing the latitudes $\left(35-36^{\circ}, 36-37^{\circ}\right.$, and $\left.>37\right)$ as 
compared to $34-35^{\circ}$ (control). At W0, W2, W3 and W4, the grain yield was first increased with increasing the latitude and then decreased with the highest GY was recorded at $36-37^{\circ}$ latitude. However, at latitudes of $35-36^{\circ}$ and $>37^{\circ}$, the GY of W5 (total water $>4000 \mathrm{~m}^{3} \mathrm{ha}^{-1}$ ) has a negative impact, as compared to $34-35^{\circ}$ (control). The effect of latitude $36-37^{\circ}$ was non-significant on GY at W5.

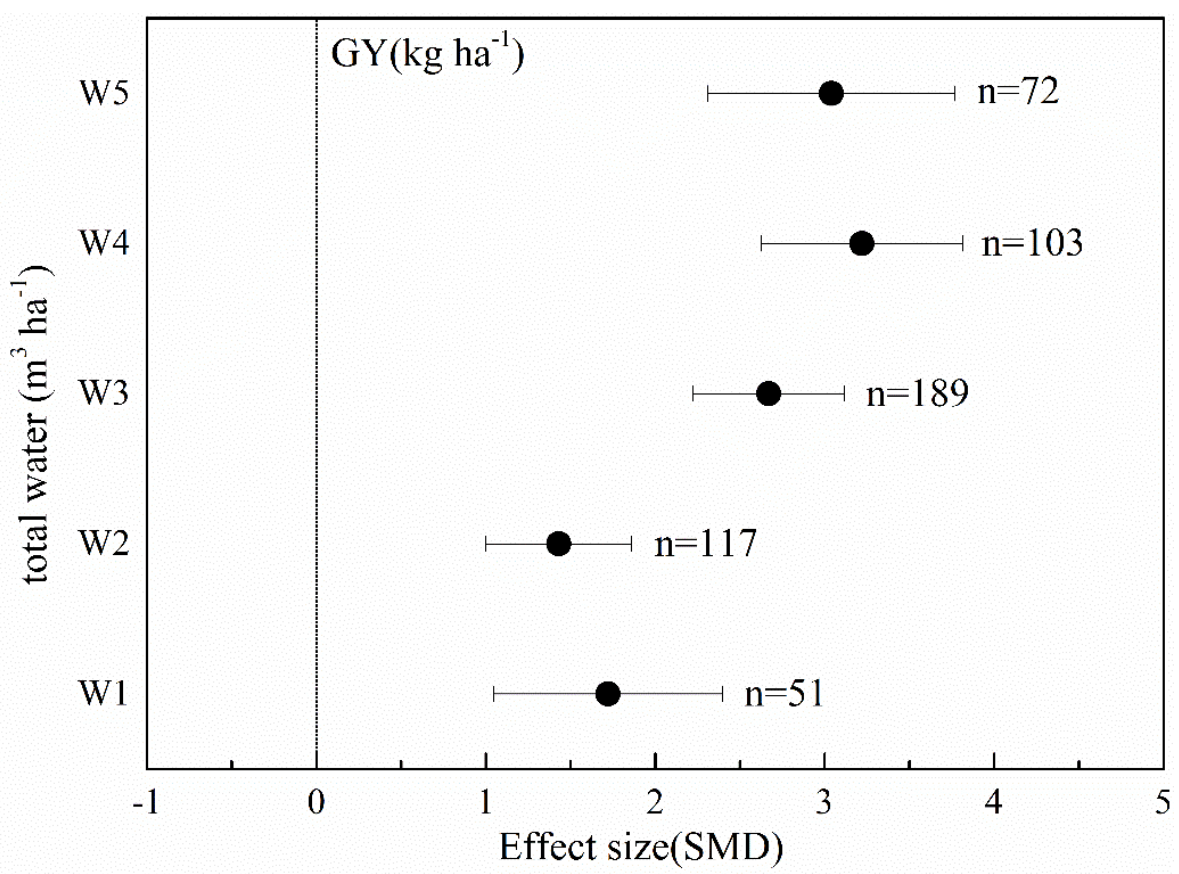

Figure 3. The relative effect size of grain yield of winter wheat under different total water, error bars represent $95 \%$ confidence interval, and $n$ values represent the corresponding number of observations. SMD: standardized mean difference; GY: grain yield
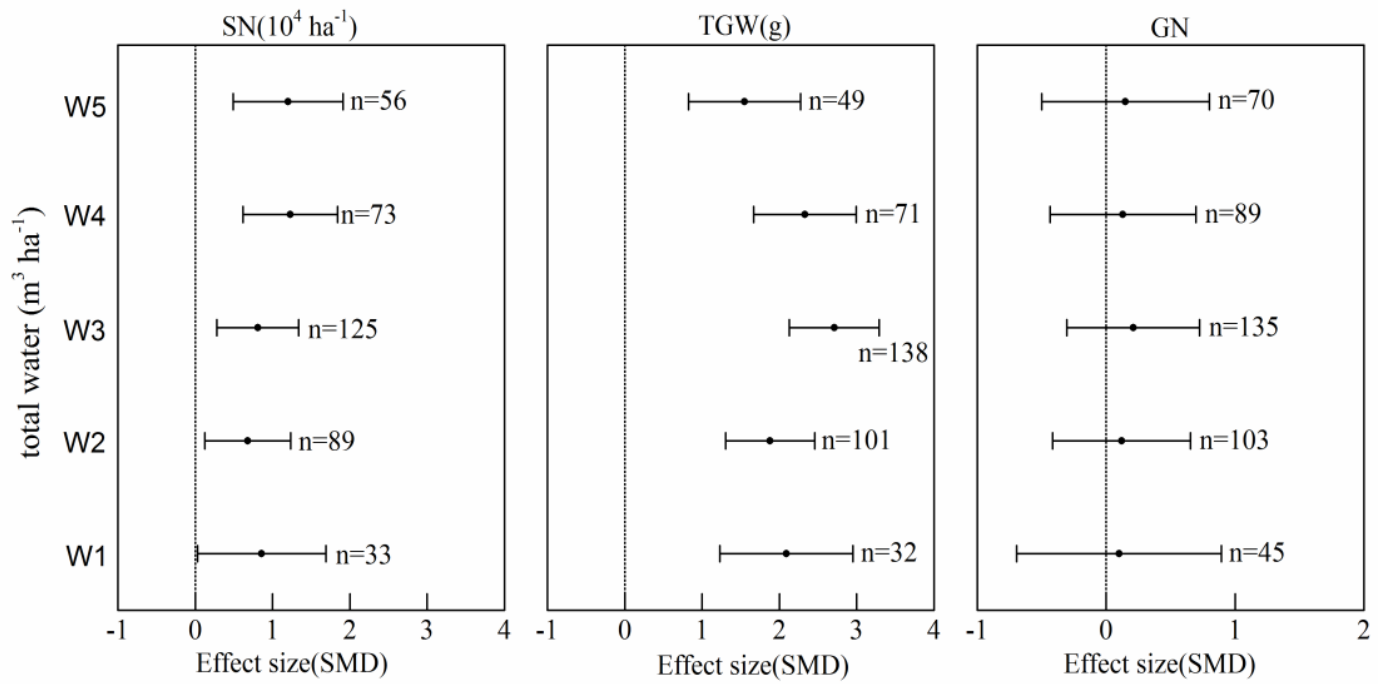

Figure 4. The relative effect size of $S N, T G W$ and $G N$ of winter wheat at different total water, error bars represent $95 \%$ confidence interval, $n$ values represent the corresponding number of observations. SMD: standardized mean difference; SN: spike number per hectare; TGW: thousand grain weight; GN: grain number per ear 

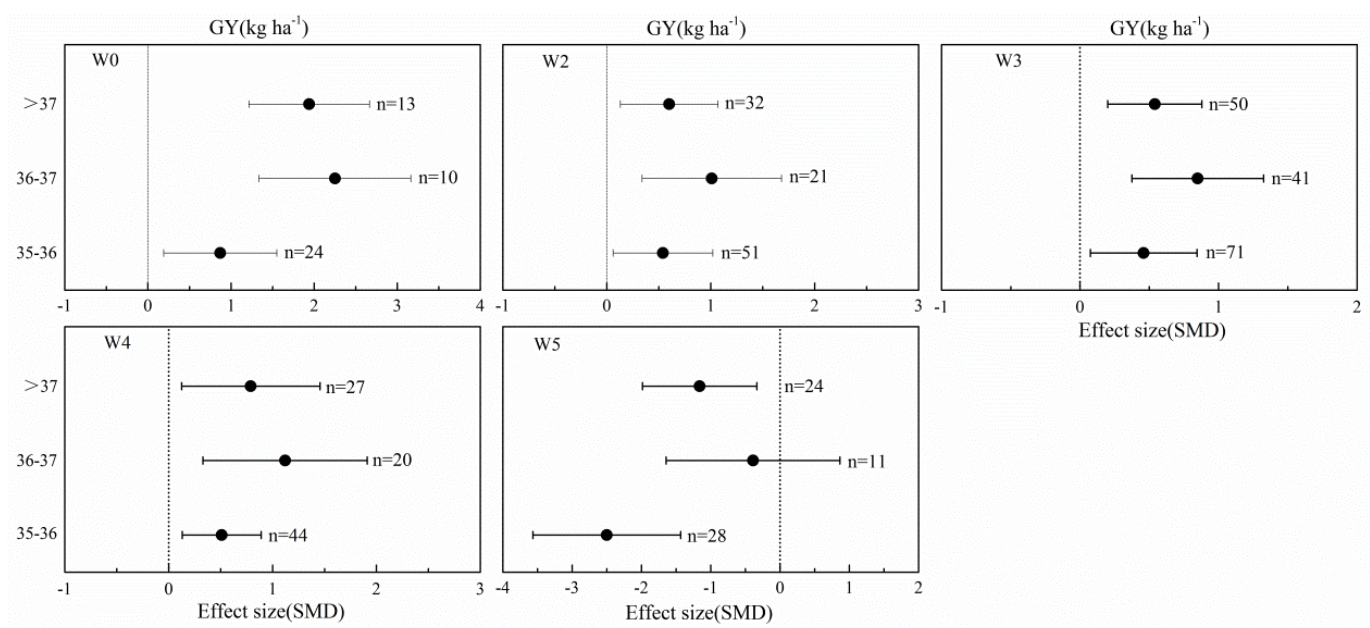

Figure 5. The effect of different latitudes on the grain yield of wheat under different total water, error bars represent $95 \%$ confidence interval, and $n$ values represent the corresponding number of observations. W0: total water 0-1000 $\mathrm{m}^{3} \mathrm{ha}^{-1}$; W2: total water 1001-2000 $\mathrm{m}^{3} \mathrm{ha}^{-1}$; W3: total water 2001-3000 $\mathrm{m}^{3} \mathrm{ha}^{-1}$; W4: total water 3001-4000 $\mathrm{m}^{3} \mathrm{ha}^{-1}$; W5: total water $>4000 \mathrm{~m}^{3} \mathrm{ha}^{-1}$

\section{Discussion}

Water plays a pivotal role in nutrient availability and other physiological processes, and a major determinant of crop yield (Adu et al., 2018). It is well known that differences in water stress can lead to differences in yield. In this study, the grain yield, spikelet numbers and thousand grains weight of winter wheat were decreased with the decrease of the total water. Previous reports have shown that wheat yield decreased with increasing the degree of water stress (Zhang et al., 2016; Jin et al., 2018). Plants responds to water stress by closing the stomatal pores in order to reduce transpiration losses, resulting in insufficient photosynthesis, reduction in crop growth, biomass accumulation and yield (Guerfel et al., 2009; Mäkinen et al., 2018). Studies have shown that spikelet numbers, grain number and thousand grains weight were directly related to wheat yield and reduced under drought stress (Shamsuddin, 1987; Kiliç and Yağbasanlar, 2010). Moderate drought affects post-anthesis biomass production and transport of photosynthetic products to kernels, thereby affecting grain weight and reducing grain yield (Liu et al., 2016). Therefore, the yield was decreased with decreasing the total water from W4 (3001-4000 $\left.\mathrm{m}^{3} \mathrm{ha}^{-1}\right)$ to W2 (1001-2000 $\left.\mathrm{m}^{3} \mathrm{ha}^{-1}\right)$. However, the effect values of grain yield, spikelet numbers and thousand grains weight at W1 (1-1000 $\mathrm{m}^{3} \mathrm{ha}^{-1}$, severe water stress) were greater than W2 (1001-2000 m $\left.\mathrm{ha}^{-1}\right)$. It may be due to the reason that drought triggers the antioxidant activity in plants and up-regulated the function of photosynthesis organs, improve leaf chlorophyll and Rubisco content through improved leaf water potential and improved photoprotection (Crafts-Brandner and Law, 2000; Abid et al., 2016). The increase in yield under W1 as compared to W2 may be related to the amount of nitrogen applied and the efficiency of nitrogen use. Proper nitrogen supply can increase cell number and volume, increase leaf photosynthetic rate and WUE, and mitigate the effects of drought stress. At low tissue water potential, nitrogen reduced the effects of drought stress on grain yield by maintaining metabolic activity, increasing leaf water potential, membrane stability index, and antioxidant activity (Zhang et al., 2007; Abid et al., 2016). Nitrogen use efficiency is generally increased in crops under water stress and higher nitrogen 
application rates increases crop drought resistance (Zhang et al., 2017b). Therefore, suitable application of water and nitrogen could enhance material accumulation, improve photosynthetic capacity, and promote grain formation. Although the data of normal nitrogen application in each experiment were extracted from this study, however, it is still impossible to rule out the effect of different nitrogen application rates on the results.

In addition, root distribution ( $>0.8 \mathrm{~m}$ ) of wheat in deep soils is critical for nutrient and water uptake, affecting wheat growth and grain yield (Dai et al., 2014; Xu et al., 2016). On the one hand, the response of wheat root system to water shortage is reduced redundancy of top root growth and increased growth of deeper roots (Song et al., 2009; White and Kirkegaard, 2010), thereby enhancing the ability of roots to absorb nutrients and water (Kaisermann et al., 2017). Some microbial groups can increase plant drought tolerance by increasing root biomass and depth to absorb water and nitrogen from deep soils to maintain growth and maintain yield (Azarbad et al., 2018; Liu et al., 2018). Under the condition of water shortage, the water evapotranspiration was decreased in the aboveground part, and more photosynthetic products were stored in the root system to improve water use efficiency. Under drought stress, nitrogen deficiency leads to increased vertical root permeability, reduced top root length density, and increased roots in deeper soil, thereby affecting grain yield (Wang et al., 2014; Xu et al., 2016). Therefore, when the total water is $\mathrm{W} 1$, the wheat yield will increase slightly, which may be the result of the wheat itself coping with stress, enhancing photosynthesis, increasing water and nitrogen use efficiency, and increasing the growth of deep roots.

It is well known that wheat production increased with increasing irrigation rate within a certain range, but as irrigation reached a certain level, WUE and yield were decreased (Trout and Dejonge, 2017; Jin et al., 2018). This study showed that the grain yield, spikelet numbers and grain weight of winter wheat were decreased by increasing total water from W4 to W5. Studies have shown that excessive irrigation reduced wheat yield mainly because of leaching of root nitrate due to excessive irrigation, resulting in insufficient nitrogen supply, causing premature root senescence and inhibiting photosynthesis, thereby reducing water and nitrogen use efficiency (Agami et al., 2018). Similarly, in loamy silty soil, excessive water tends to cause hypoxia in the root zone of the crop, thereby damaging the roots and reducing yield (Mäkinen et al., 2018). In addition, excessive irrigation of wheat can easily lead to lodging, leaf rust or mildew, affecting normal wheat growth (Bennett, 1984; Roelfs et al., 1992).

Previous studies showed that drought stress significantly reduced spikelet numbers, grain numbers and grain weight of wheat, and reduction in grain numbers had the greatest direct impact on grain yield (Simane et al., 1993). However, in the present study, water stress had no significant effect on grain numbers. Wheat grain yield formation and grain number are genetically controlled but also affected by the environment (Wang et al., 2014). The drought resistance and yield potential of different varieties were different in the 53 collected studies. For example, water stress was applied during wheat microspore stage, and drought resistant wheat variety SYN604 was having more number of grains than Sundor which is drought resistant variety (Ji et al., 2010). In addition, the stage of differentiation of young spikes before flowering is the key period for the formation of $\mathrm{GN}$, this period determines the number of fertile flowers in wheat spikelets, which determines GN. Studies have shown that during meiosis of pollen development in wheat, water stress blocks the relationship between pollen grains and tapetal layer during microspore stage, degenerates the filaments, and 
the pollen grains cannot accumulate starch, resulting in nutrient deficiency and affecting pollen development, leads to a decrease in GN (Saini et al., 1984; Cattivelli et al., 2008). Moreover, under severe water stress, the use of male sterile materials to study the effects of wheat microspores stage on GN found that GN were decreased by $16.4 \%$ ( $\mathrm{Ji}$ et al., 2010), even under mild water stress, starch accumulation and sucrose transport in the ovary are also severely affected. It indicated that the development of ovary under water stress had a certain effect on GN. Some studies have shown that under water stress, the cell wall invertase viability of sucrose transport in wheat anthers is related to pollen sterility, which is characterized by decreased cell wall invertase viability, blocked sucrose transport, and a large accumulation of sucrose in anthers, causes changes in the metabolism of other soluble sugars leading to infertility (Dorion et al., 1996; Koonjul et al., 2005; Ji et al., 2010). It can be seen that the reason that water stress has no significant effect on GN may be due to the combined effects of variety and water in this study.

Latitude is an important geographic factor which affects temperature and solar radiation, thus affecting the duration of crop growth and yield (Liu et al., 2010, 2013b). This study showed that under different irrigation rate (except $>4000 \mathrm{~m}^{3} \mathrm{ha}^{-1}$ ), with the increase of latitude, the yield was first increased and then decreased. The maximum yield was attained at $36-37^{\circ}$. Similarly, Li (2010) indicated that with the increase of latitude in Henan Province, the yield of different wheat varieties was increased first and then decreased. Due to the large latitude span of China's wheat growing areas, the temperature difference is large, and the effect of temperature changes on wheat yield is not negligible (Asseng et al., 2011). In this study, the yield at latitude $35-36^{\circ}$ (except for $>4000 \mathrm{~m}^{3} \mathrm{ha}^{-1}$ ) was lower than $36-37^{\circ}$, which might be due attributed to the high temperature at low latitude and increasing temperature resulting in decrease of yield. There are significant changes in climatic variables at different altitudes, which in turn affect the development and yield of winter wheat (Xiao et al., 2008). Dryland wheat yield is highest at medium elevations with sufficient precipitation and mild temperatures. At high elevations, temperatures are too low to allow the crops to mature with fewer yields.

Higher temperatures shorten the wheat growing season, which leads to a shortening of the grain filling period and a decrease in wheat yield (Dias and Lidon, 2010; Xiao et al., 2010; Asseng et al., 2011). The decline in wheat yield with increasing temperature is mainly due to less spikelet numbers (Asseng et al., 2015). Elevated temperatures also increase evapotranspiration (Trnka et al., 2012; Liu et al., 2013a), reducing soil water content, increasing water stress, and thereby reducing wheat yield (Qin et al., 2018; Li et al., 2019). At high altitude, the wheat yield might be affected by various other interacting factors such as region, climate, variety, soil texture (Tapley et al., 2013; Daryanto et al., 2016; Zhang et al., 2017b).

\section{Conclusion}

The results from meta-analysis method showed that the grain yield, spikelet number and grain weight of winter wheat were significantly affected by the total water, whereas, effect of total water was not significant on grain number. Yield and yield components were not increased by increasing total water from $\mathrm{W} 1\left(1-1000 \mathrm{~m}^{3} \mathrm{ha}^{-1}\right)$ to $\mathrm{W} 2$ (1001-2000 $\left.\mathrm{m}^{3} \mathrm{ha}^{-1}\right)$. Grain yield and spike numbers were increased by further increasing total water with maximum at W4 (3001-4000 $\left.\mathrm{m}^{3} \mathrm{ha}^{-1}\right)$. At $\mathrm{W} 4$, grain yield 
and spike numbers were $148.5 \%$ and $39.7 \%$ higher as compared to control, indicating that W4 was optimal total water. Thousand grain weight was highest at W3 (2001-3000 $\mathrm{m}^{3} \mathrm{ha}^{-1}$ ) with $79.7 \%$ increase as compared to control (total water is 0 ). Under different total water, grain yield was increased with increasing latitude from $35-36^{\circ}$ to $36-37^{\circ}$ and then decreases at latitude $>37^{\circ}$, and the specific reasons for decline in yield at high latitude remain to be further studied.

Acknowledgements. This work was supported by National Natural Science Foundation of China (31871571, 31371572), Outstanding Doctor Funding Award of Shanxi Province (SXYBKY2018040), Key Technologies R\&D Program of Shanxi Province (201603D221037-3) and China Postdoctoral Science Foundation (2017M621105).

\section{REFERENCES}

[1] Abid, M., Tian, Z. W., Ata-Ul-Karim, S. T., Liu, Y., Cui, Y. K., Zahoor, R. (2016): Improved tolerance to post-anthesis drought stress by pre-drought priming at vegetative stages in drought-tolerant and -sensitive wheat cultivars. - Plant Physiology and Biochemistry 106: 218-227.

[2] Adu, M. O., Yawson, D. O., Armah, F. A., Asare, P. A., Frimpong, K. A. (2018): Metaanalysis of crop yields of full, deficit, and partial root-zone drying irrigation. Agricultural Water Management 197: 79-90.

[3] Agami, R. A., Alamri, S. A. M., El-Mageed, T. A. A., Abousekken, M. S. M., Hashem M. (2018): Role of exogenous nitrogen supply in alleviating the deficit irrigation stress in wheat plants. - Agricultural Water Management 210: 261-270.

[4] Asseng, S., Foster, I., Turner, N. C. (2011): The impact of temperature variability on wheat yields. - Global Change Biology 17(2): 997-1012.

[5] Asseng, S., Ewert, F., Martre, P., Rötter, R. P., Lobell, D. B., Cammarano, D., Kimball, B. A., Ottman, M. J., Wall, G. W., White, J. W., Reynolds, M. P., Alderman, P. D., Prasad, P. V. V., Aggarwal, P. K., Anothai, J., Basso, B., Biernath, C., Challinor, A. J., De Sanctis, G., Doltra, J., Fereres, E., Garcia-Vila, M., Gayler, S., Hoogenboom, G., Hunt, L. A., Izaurralde, R. C., Jabloun, M., Jones, C. D., Kersebaum, K. C., Koehler, A.-K., Müller, C., Naresh Kumar, S., Nendel, C., O’Leary, G., Olesen, J. E., Palosuo, T., Priesack, E., Eyshi Rezaei, E., Ruane, A. C., Semenov, M. A., Shcherbak, I., Stöckle, C., Stratonovitch, P., Streck, T., Supit, I., Tao, F., Thorburn, P. J., Waha, K., Wang, E., Wallach, D., Wolf, J., Zhao, Z., Zhu, Y. (2015): Rising temperatures reduce global wheat production. - Nature Climate Change 5: 143-147.

[6] Azarbad, H., Constant, P., Giard-Laliberté, C., Bainard, L. D., Yergeau, E. (2018): Water stress history and wheat genotype modulate rhizosphere microbial response to drought. Soil Biology \& Biochemistry 126: 228-236.

[7] Bennett, F. G. A. (1984): Resistance to powdery mildew in wheat: a review of its use in agriculture and breeding programmes. - Plant Pathology 33: 279-300.

[8] Cai, X. L., Molden, D., Mainuddin, M., Sharma, B., Ahmad, M. D., Karimi, P. (2011): Producing more food with less water in a changing world: assessment of water productivity in 10 major river basins. - Water International 36(1): 42-62.

[9] Cattivelli, L., Rizza, F., Badeck, F. W., Mazzucotelli, E., Mastrangelo, A. M., Francia, E., Marè, C., Tondelli, A., Stanca, A. M. (2008): Drought tolerance improvement in crop plants: An integrated view from breeding to genomics. - Field Crops Research 105(1-2): $1-14$.

[10] Crafts-Brandner, S. J., Law, R. D. (2000): Effect of heat stress on the inhibition and recovery of the ribulose-1, 5-bisphosphate carboxylase/oxygenase activation state. Planta 212(1): 67-74. 
[11] Dai, A. (2012): Increasing drought under global warming in observations and models. Nature Climate Change 3: 52-58.

[12] Dai, X. L., Xiao, L. L., Jia, D. Y., Kong, H. B., Wang, Y. C., Li, C. X., Zhang, Y., He, M. R. (2014): Increased plant density of winter wheat can enhance nitrogen-uptake from deep soil. - Plant and Soil 384(1-2): 141-152.

[13] Daryanto, S., Wang, L. X., Jacinthe, P. (2016): Global synthesis of drought effects on cereal, legume, tuber and root crops production: A review. - Agricultural Water Management 179(1): 18-33.

[14] Dias, A. S., Lidon, F. C. (2010): Evaluation of grain filling rate and duration in bread and durum wheat, under heat stress after anthesis. - Journal of Agronomy and Crop Science 195(2): 137-147.

[15] Dorion, S., Lalonde, S., Saini, H. S. (1996): Induction of male sterility in wheat by meiotic-stage water deficit is preceded by a decline in invertase activity and changes in carbohydrate metabolism in anthers. - Plant Physiology 111(1): 137-145.

[16] Du, T. S., Kang, S. Z., Sun, J. S., Zhang, X. Y., Zhang, J. H. (2010): An improved water use efficiency of cereals under temporal and spatial deficit irrigation in north China. Agricultural Water Management 97(1): 66-74.

[17] Farhangfar, S., Bannayan, M., Khazaei, H. R., Baygi, M. M. (2015): Vulnerability assessment of wheat and maize production affected by drought and climate change. International Journal of Disaster Risk Reduction 13: 37-51.

[18] Giunta, F., Motzo, R., Deidda, M. (1993): Effect of drought on yield and yield components of durum wheat and triticale in a mediterranean environment. - Field Crops Research 33(4): 399-409.

[19] Guerfel, M., Beis, A., Zotos, T., Boujnah, D., Zarrouk, M., Patakas, A. (2009): Differences in abscisic acid concentration in roots and leaves of two young olive (Olea europaea L.) cultivars in response to water deficit. - Acta Physiologiae Plantarum 31(4): 825-831.

[20] Hedges, L. V., Olkin, I. (1985): Statistical methods for meta-analysis. - Academie Press, New York.

[21] Hedges, L. V., Gurevitch, J., Curtis, P. S. (1999): The meta-analysis of response ratios in experimental ecology. - Ecology 80(4): 1150-1156.

[22] Ji, X. M., Shiran, B., Wan, J. L., Lewis, D. C., Jenkins, C. L. D., Condon, A. G., Richards, R. A., Dolferus, R. (2010): Importance of pre-anthesis anther sink strength for maintenance of grain number during reproductive stage water stress in wheat. - Plant, \& Cell Environment 33(6): 926-942.

[23] Jin, N., Ren, W., Tao, B., He, L., Ren, Q. F., Li, S. Q., Yu, Q. (2018): Effects of water stress on water use efficiency of irrigated and rainfed wheat in the loess plateau, China.Science of The Total Environment 642: 1-11.

[24] Kaisermann, A., Vries, F. T., Griffiths, R. I., Bardgett, R. D. (2017): Legacy effects of drought on plant-soil feedbacks and plant-plant interactions. - New Phytologist 215(4): 1413-1424.

[25] Kiliç, H., Yağbasanlar, T. (2010): The effect of drought stress on grain yield, yield components and some quality traits of durum wheat (triticum turgidum ssp. durum) cultivars. - Notulae Botanicae Horti Agrobotanici Cluj-Napoca 38(1): 164-170.

[26] Koonjul, P. K., Minhas, J. S., Nunes, C., Sheoran, I. S., Saini, H. S. (2005): Selective transcriptional down-regulation of anther invertases precedes the failure of pollen development in water-stressed wheat. - Journal of Experimental Botany 56(409): 179190.

[27] Li, L. (2010): The Analysis of Changes and Utilization Of Climatic Resources and Wheat Potential Productive In Different Latitudes Of Henan Province. - Henan Agricultural University. 
[28] Li, J. Z., Dong, W. X., Oenema, O., Chen, T., Hu, C. S., Yuan, H. J., Zhao, L. Y. (2019): Irrigation reduces the negative effect of global warming on winter wheat yield and greenhouse gas intensity. - Science of the Total Environment 646: 290-299.

[29] Liu, Y., Wang, E. L., Yang, X. G., Wang, J. (2010): Contributions of climatic and crop varietal changes to crop production in the north china plain, since 1980s. - Global Change Biology 16(8): 2287-2299.

[30] Liu, L. T., Hu, C. S., Olesen, J. E., Ju, Z. Q., Yang, P. P., Zhang, Y. M. (2013a): Warming and nitrogen fertilization effects on winter wheat yields in northern china varied between four years. - Field Crops Research 151: 56-64.

[31] Liu, Y. E., Xie, R. Z., Hou, P., Li, S. K., Zhang, H. B., Ming, B., Long, H. L., Liang, S. M. (2013b): Phenological responses of maize to changes in environment when grown at different latitudes in China. - Field Crops Research 144: 192-199.

[32] Liu, E. K., Mei, X. R., Yan, C. R., Gong, D. Z., Zhang, Y. Q. (2016): Effects of water stress on photosynthetic characteristics, dry matter translocation and wue in two winter wheat genotypes. - Agricultural Water Management 167: 75-85.

[33] Liu, W., Ma, G., Wang, C., Wang, J., Lu, H., Li, S., Feng, W., Xie, Y., Ma, D., Kang, G. (2018): Irrigation and Nitrogen Regimes Promote the Use of Soil Water and Nitrate Nitrogen from Deep Soil Layers by Regulating Root Growth in Wheat. - Frontiers in Plant Science 9: 32.

[34] Mäkinen, H., Kaseva, J., Trnka, M., Balek, J., Kersebaum, K. C., Nendel, C., Gobin, A., Olesen, J. E., Bindi, M., Ferrise, R., Moriondo, M., Rodríguez, A., Ruiz-Ramos, M., Takáč, J., Bezák, P., Ventrella, D., Ruget, F., Capellades, G., Kahiluoto, H. (2018): Sensitivity of European wheat to extreme weather. - Field Crops Research 222: 209-217.

[35] Qin, X. B., Wang, H., He, Y., Li, Y. E., Li, Z. G., Gao, Q. Z., Wan, Y. F., Qian, B. D., McConkey, B., DePauw, R., Lemke, R., Parton, W. J. (2018): Simulated adaptation strategies for spring wheat to climate change in a northern high latitude environment by DAYCENT model. - European Journal of Agronomy 95: 45-56.

[36] Reyer, C. P. O., Leuzinger, S., Rammig, A., Wolf, A., Bartholomeus, R. P., Bonfante, A., de Lorenzi, F., Dury, M., Gloning, P., Jaoudé, R. A., Klein, T., Kuster, T. M., Martins, M., Niedrist, G., Riccardi, M., Wohlfahrt, G., de Angelis, P., de Dato, G., François, L., Menzel, A., Pereira, M. (2013): A plant's perspective of extremes: terrestrial plant responses to changing climatic variability. - Global Change Biology 19(1): 75-89.

[37] Roelfs, A. P. (1992): Rust diseases of wheat: concepts and methods of disease management. - CIMMYT Publishing, Mexico.

[38] Rossini, M., Fava, F., Cogliati, S., Meroni, M., Marchesi, A., Panigada, C., Giardino, C., Busetto, L., Migliavacca, M., Amaducci, S., Colombo, R. (2013): Assessing canopy PRI from airborne imagery to map water stress in maize. - ISPRS Journal of Photogrammetry and Remote Sensing 86: 168-177.

[39] Saini, H. S., Sedgley, M., Aspinall, D. (1984): Development anatomy in wheat of male sterility induced by heat stress, water deficit or abscisic acid. - Functional Plant Biology 11(4): 243-253.

[40] Sauer, T., Havlík, P., Schneider, U. A., Schmid, E., Kindermann, G., Obersteiner, M. (2010): Agriculture and resource availability in a changing world: The role of irrigation. Water Resources Research 46(6): 666-669.

[41] Shamsuddin, A. K. M. (1987): Path analysis in bread-wheat. - Indian Journal of Agricultural Sciences 57(1): 47-49.

[42] Simane, B., Struik, P. C., Nachit, M. M., Peacock, J. M. (1993): Ontogenetic analysis of yield components and yield stability of durum wheat in water-limited environments. Euphytica 71(3): 211-219.

[43] Smithers, L. G., Gibson, R. A., Mcphee, A. J., Makrides, M. (2008): Effect of long-chain polyunsaturated fatty acid supplementation of preterm infants on disease risk and neurodevelopment: a systematic review of randomized controlled trials. - American Journal of Clinical Nutrition 87(4): 912-920. 
[44] Song, L., Li, F. M., Fan, X. W., Xiong, Y. C., Wang, W. Q., Wu, X. B., Turner, N. C. (2009): Soil water availability and plant competition affect the yield of spring wheat. European Journal of Agronomy 31(1): 51-60.

[45] Tapley, M., Ortiz, B. V., Santen, E. V., Balkcom, K. S., Mask, P., Weaver, D. B. (2013): Location, seeding date, and variety interactions on winter wheat yield in southeastern united states. - Agronomy Journal 105: 509-518.

[46] Trnka, M., Brázdil, R., Olesen, J. E., Eitzinger, J., Zahradníček, P., Kocmánková, E., Dobrovolný, P., Štěpánek, P., Možný, M., Bartošová, L., Hlavinka, P., Semerádová, D., Valášek, H., Havlíček, M., Horáková, V., Fischer, M., Žalud, Z. (2012): Could the changes in regional crop yields be a pointer of climatic change. - Agricultural and Forest Meteorology 166-167: 62-71.

[47] Trout, T. J., Dejonge, K. C. (2017): Water productivity of maize in the us high plains. Irrigation Science 35(3): 251-266.

[48] Wang, C. Y., Liu, W. X., Li, Q. X., Ma, D. Y., Lu, H. F., Feng, W., Xie, Y., Zhu, Y., Guo, T. C. (2014): Effects of different irrigation and nitrogen regimes on root growth and its correlation with above-ground plant parts in high-yielding wheat under field conditions. Field Crops Research 165: 138-149.

[49] Wei, T., Dong, Z. Y., Zhang, C., Ali, S., Chen, X. L., Han, Q. F., Zhang, F. C., Jia, Z., Zhang, P., Ren, X. (2018): Effects of rainwater harvesting planting combined with deficiency irrigation on soil water use efficiency and winter wheat (Triticum aestivum L.) yield in a semiarid area. - Field Crops Research 218: 231-242.

[50] White, R. G., Kirkegaard, J. A. (2010): The distribution and abundance of wheat roots in a dense, structured subsoil-implications for water uptake. - Plant, Cell \& Environment 33(2): 133-148.

[51] Xiao, G. J., Zhang, Q., Yao, Y. B., Zhao, H., Wang, R. Y., Bai, H. Z., Zhang, F. J. (2008): Impact of recent climatic change on the yield of winter wheat at low and high altitudes in semi-arid northwestern China. - Agriculture, Ecosystems \& Environment 127(1-2): 37-42.

[52] Xiao, G. J., Zhang, Q., Li, Y., Wang, R. Y., Yao, Y. B., Zhao, H., Bai, H. Z. (2010): Impact of temperature increase on the yield of winter wheat at low and high altitudes in semiarid northwestern China. - Agricultural Water Management 97(9): 1360-1364.

[53] Xu, C. L., Tao, H. B., Tian, B. J., Gao, Y. B., Ren, J. H., Wang, P. (2016): Limitedirrigation improves water use efficiency and soil reservoir capacity through regulating root and canopy growth of winter wheat. - Field Crops Research 196: 268-275.

[54] Zhang, L. X., Li, S. X., Zhang, H., Liang, Z. S. (2007): Nitrogen rates and water stress effects on production, lipid peroxidation and antioxidative enzyme activities in two maize (zea mays 1.) genotypes. - Journal of Agronomy and Crop Science 193(6): 387-397.

[55] Zhang, K., Chen, N. L., Gu, Q. Y. (2016): Trade-offs among light, water and nitrogen use efficiencies of wheat cultivars under different water and nitrogen application levels. Chinese Journal of Applied Ecology 27(7): 2273-2282.

[56] Zhang, H. H., Han, M., Chávez, J. L., Lan, Y. B. (2017a): Improvement in estimation of soil water deficit by integrating airborne imagery data into a soil water balance model. International Journal of Agricultural and Biological Engineering 10(3): 37-46.

[57] Zhang, X. Y., Qin, W. L., Chen, S. Y., Shao, L. W., Sun, H. Y. (2017b): Responses of yield and WUE of winter wheat to water stress during the past three decades-a case study in the north china plain. - Agricultural Water Management 179: 47-54. 